\title{
Novel Techniques in the Surgical Treatment of Acromegaly: Applications and Efficacy
}

\author{
Michael Buchfelder Sven-Martin Schlaffer \\ Department of Neurosurgery, Friedrich-Alexander-Universität Erlangen-Nürnberg, Erlangen, Germany
}

\begin{abstract}
Key Words
Acromegaly · Surgical treatment · Endoscopy . Intraoperative magnetic resonance imaging · Neuronavigation · Ultrasound · Doppler probe
\end{abstract}

\begin{abstract}
Since the establishment of transsphenoidal microsurgery as the operative treatment of choice in most patients with acromegaly 40 years ago, a few novel technical developments have evolved. Their application, utility and efficacy will be briefly discussed in this review article, based on an analysis of published results and the authors' personal experience. The endoscope was additionally used to search for residual tumours in locations which could not be visualised with the operating microscope. In many centres it has by now fully replaced the operating microscope. Extended endoscopic operations hardly have limits in respect to accessible pathology. Overall, the results and complications reported from microsurgical and endoscopic series are comparable. Intraoperative magnetic resonance imaging allows depicting the completeness of a tumour resection. While in many patients additional tumour resections are performed on the basis of intraoperative imaging, the improvements in hormonal remission rates reported are less impressive. Neuronavigation uses imaging data to improve the surgeon's orientation, and it is certainly a major asset to the inexperienced. In high-
\end{abstract}

caseload centres it is mainly appreciated in anatomical variants and reoperations. While the Doppler probe is a valuable and easily affordable gadget to avoid vascular arterial injury, intraoperative ultrasound imaging of tumour extension has a much poorer resolution than magnetic resonance imaging and is thus not widely implemented. The clinical value of intraoperative growth hormone measurements is controversially discussed. In summary, the application of modern technology has only led to a minor improvement of results, but it has widened the spectrum of accessible pathologies and increased the safety of the procedures for the patient. It is expected that outcomes will continue to improve as novel techniques and concepts are being developed.

๑) 2016 S. Karger AG, Basel

\section{Introduction}

For the majority of patients with acromegaly, the primary therapy to date consists of surgery $[1,2]$. The operative techniques used have undergone an evolution of more than 100 years. After resection of the growth hormone (GH)-secreting tumour tissue, many patients achieve biochemical remission, even when the most recent, stringent criteria are applied [3]. Several studies have shown that a normalisation of GH levels decreases mortality [4-7]. Therefore, aggressive surgical manage-

\section{KARGER}

E-Mail karger@karger.com

www.karger.com/nen
(C) 2016 S. Karger AG, Basel

0028-3835/16/1031-0032\$39.50/0
Michael Buchfelder or Sven-Martin Schlaffer

Department of Neurosurgery

Friedrich-Alexander-Universität Erlangen-Nürnberg

Schwabachanlage 6, DE-91054 Erlangen (Germany)

E-Mail michael.buchfelder@uk-erlangen.de or sven.schlaffer@uk-erlangen.de 
Fig. 1. Endoscopic views during transsphenoidal resection of a pituitary microadenoma in an acromegalic patient. a Resection of septations within the sphenoid sinus. b Drilling of the sellar floor. c Resection of the microadenoma. d Reconstruction of the sellar floor.
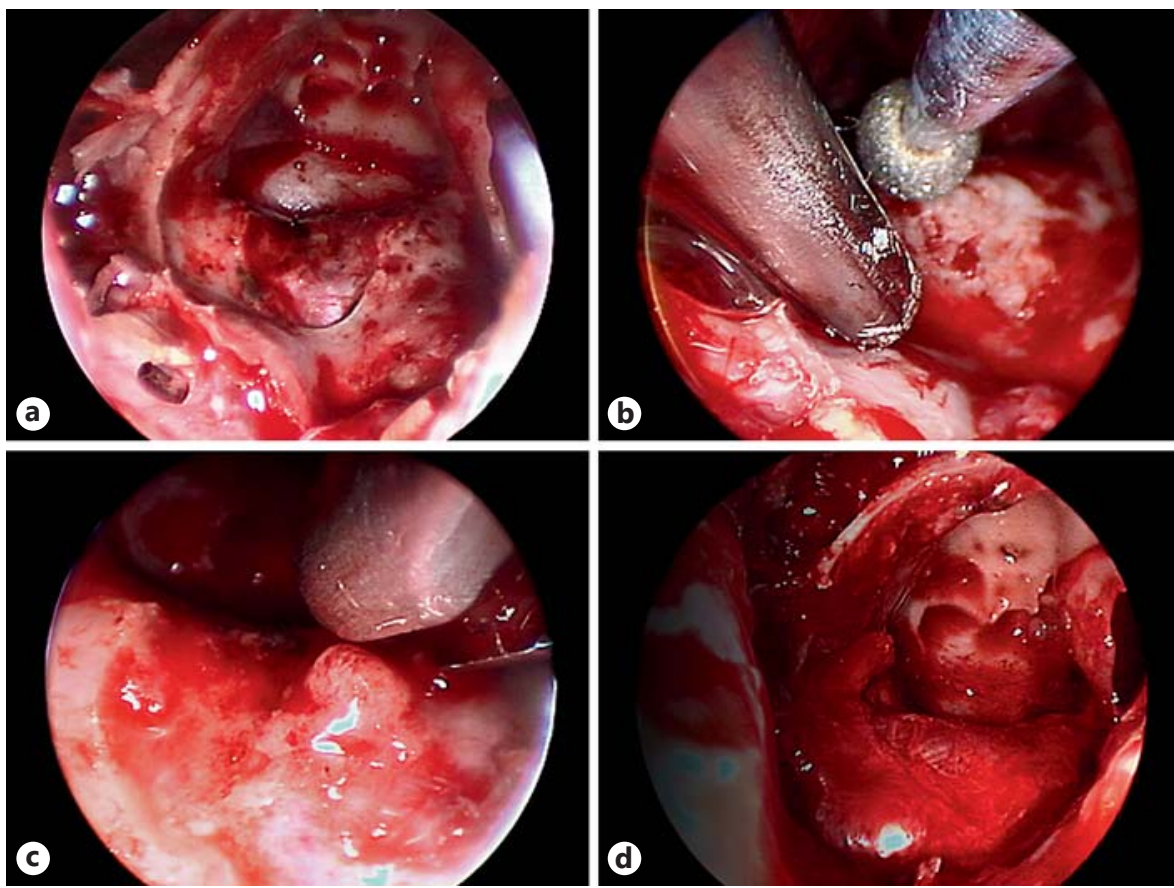

ment to lower serum GH levels is necessary once the diagnosis is confirmed, which aims at the utmost possible tumour extraction. The goals of surgical therapy in acromegaly include the normalisation of $\mathrm{GH}$ and insulin-like growth factor (IGF)-1 secretions, preservation of normal pituitary function and elimination of the mass effect of the tumour.

Over time, the definition of disease remission in acromegaly has changed dramatically $[3,8]$. International consensus conferences formulated modern definitions of cure. Despite the current criteria for remission [3], most large surgical series still use the remission criteria defined at the Cortina Consensus Conference [8]. Usually, the endocrinological evaluation which helps decide on whether the disease is remitting or persistent is performed 2-3 months after the operation. However, the surgical results, as measured by a normalisation of IGF-1 levels, total tumour resection and the avoidance of complications, are also dependent on the experience of the individual neurosurgeon and the caseload of the surgical centre $[9,10]$.

Worldwide, the vast majority of patients undergo transsphenoidal surgery, while transcranial approaches are only required in a few patients with tumour masses predominantly outside the sella turcica [9]. The operations are largely standardised, efficient and safe $[11,12]$. Moreover, surgery is also a relatively cheap treatment and frequently leads to permanent remission. Many patients

Novel Techniques in Surgery of Acromegaly require additional medical therapies or irradiation postoperatively [13-15]. New technical possibilities have allowed novel surgical techniques and strategies or variants of established procedures [9].

This paper comments on technical advances which have been introduced and investigated since transsphenoidal microsurgery was established as the operative treatment of choice for pituitary adenomas causing acromegaly.

\section{Endoscopy}

Based on the pivotal series of Jho and Carrau [16], endoscopic transsphenoidal surgery has evolved considerably in the past 20 years. The principle of endoscopy is that the lens, which represents the eye of the surgeon, and a powerful source of light are advanced into the sphenoid sinus or even into the tumour cavity. A much more panoramic view results from this approach in comparison to transsphenoidal microsurgery (fig. 1). Moreover, one of the major restrictions of microsurgery, namely the dependency on a straight line of sight, is eliminated. Variously angled endoscopes allow the direct visualisation of structures clearly outside the limitations set by the blades of the speculum, which is needed in the microsurgical approach. 
Table 1. Results of purely endoscopic transsphenoidal surgery in acromegaly: an overview of selected series

\begin{tabular}{|c|c|c|c|c|c|c|}
\hline \multirow[t]{2}{*}{ Authors [Ref.] } & \multirow[t]{2}{*}{ Year } & \multicolumn{2}{|c|}{ Adenoma } & \multirow{2}{*}{$\begin{array}{l}\text { Remission, } \\
\%\end{array}$} & \multirow[t]{2}{*}{ Remission criteria } & \multirow{2}{*}{$\begin{array}{l}\text { Factors associated with } \\
\text { favourable outcome }\end{array}$} \\
\hline & & $\mathrm{n}$ & type & & & \\
\hline $\begin{array}{l}\text { Campbell et al. [4] } \\
\text { (Philadelphia, Pa., USA) }\end{array}$ & 2010 & $\begin{array}{r}4 \\
22\end{array}$ & $\begin{array}{l}\text { microadenomas } \\
\text { macroadenomas }\end{array}$ & $\begin{array}{l}75 \\
54.5\end{array}$ & $\begin{array}{l}\mathrm{GH}<2.5 \mathrm{ng} / \mathrm{ml} ; \\
\mathrm{GH} \text { after OGTT }<1 \mathrm{ng} / \mathrm{ml} ; \\
\text { IGF-1 normal }\end{array}$ & $\begin{array}{l}\text { lower Knosp grade; } \\
\text { lower Hardy-Wilson stage }\end{array}$ \\
\hline $\begin{array}{l}\text { Hofstetter et al. [47] } \\
\text { (New York, N.Y., USA) }\end{array}$ & 2010 & $\begin{array}{r}4 \\
20\end{array}$ & $\begin{array}{l}\text { microadenomas } \\
\text { macroadenomas }\end{array}$ & $\begin{array}{l}38 \\
\text { (overall) }\end{array}$ & $\begin{array}{l}\mathrm{GH}<1 \mathrm{ng} / \mathrm{ml} \text { or } \\
\mathrm{GH} \text { after OGTT }<0.4 \mathrm{ng} / \mathrm{ml} \text {; } \\
\text { IGF-1 normal }\end{array}$ & \\
\hline $\begin{array}{l}\text { Yildirim et al. [48] } \\
\text { (Ankara, Turkey) }\end{array}$ & 2014 & $\begin{array}{r}5 \\
51\end{array}$ & $\begin{array}{l}\text { microadenomas } \\
\text { macroadenomas }\end{array}$ & $\begin{array}{l}80 \\
64.7\end{array}$ & $\begin{array}{l}\mathrm{GH}<1 \mathrm{ng} / \mathrm{ml} \text { or } \\
\mathrm{GH} \text { after OGTT }<0.4 \mathrm{ng} / \mathrm{ml} \text {; } \\
\text { IGF-1 normal }\end{array}$ & \\
\hline $\begin{array}{l}\text { Gondim et al. [49] } \\
\text { (Fortaleza, Brazil) }\end{array}$ & 2010 & $\begin{array}{l}14 \\
53\end{array}$ & $\begin{array}{l}\text { microadenomas } \\
\text { macroadenomas }\end{array}$ & $\begin{array}{l}74.2 \\
71.7\end{array}$ & $\begin{array}{l}\text { GH after OGTT }<1 \mathrm{ng} / \mathrm{ml} \text {; } \\
\text { IGF-1 normal }\end{array}$ & \\
\hline $\begin{array}{l}\text { Jane et al. [19] } \\
\text { (Charlottesville, Va., USA) }\end{array}$ & 2011 & $\begin{array}{l}14 \\
46 \\
24 \\
22\end{array}$ & $\begin{array}{l}\text { microadenomas } \\
\text { macroadenomas } \\
\text { adenomas } 1-2 \mathrm{~cm} \\
\text { adenomas }>2 \mathrm{~cm}\end{array}$ & $\begin{array}{l}100 \\
60.9 \\
75 \\
45.5\end{array}$ & $\begin{array}{l}\mathrm{GH}<1 \mathrm{ng} / \mathrm{ml} \text { or } \\
\mathrm{GH} \text { after OGTT }<0.4 \mathrm{ng} / \mathrm{ml} \text {; } \\
\mathrm{IGF}-1 \text { normal }\end{array}$ & $\begin{array}{l}\text { smaller tumour size; } \\
\text { lower Knosp grade; } \\
\text { preoperative GH/IGF-1; } \\
\text { in-hospital GH }<2.5 \mathrm{ng} / \mathrm{m} \\
\text { during first } 2 \text { days p.o. }\end{array}$ \\
\hline $\begin{array}{l}\text { Starke et al. [20] } \\
\text { (Charlottesville, Va., USA) }\end{array}$ & 2013 & $\begin{array}{l}13 \\
59\end{array}$ & $\begin{array}{l}\text { microadenomas } \\
\text { macroadenomas }\end{array}$ & $\begin{array}{l}92.3 \\
66.1\end{array}$ & $\begin{array}{l}\mathrm{GH}<1 \mathrm{ng} / \mathrm{ml} \text { or } \\
\mathrm{GH} \text { after OGTT }<0.4 \mathrm{ng} / \mathrm{ml} \text {; } \\
\text { IGF-1 normal }\end{array}$ & \\
\hline $\begin{array}{l}\text { Shin et al. [50] } \\
\text { (Pittsburgh, Pa., USA) }\end{array}$ & 2013 & $\begin{array}{r}45 \\
6\end{array}$ & $\begin{array}{l}\text { macroadenomas } \\
\text { microadenomas }\end{array}$ & $\begin{array}{l}83.3 \\
46.7\end{array}$ & $\begin{array}{l}\mathrm{GH}<1 \mathrm{ng} / \mathrm{ml} \text { or } \\
\mathrm{GH} \text { after OGTT }<0.4 \mathrm{ng} / \mathrm{ml} \text {; } \\
\text { IGF-1 normal }\end{array}$ & $\begin{array}{l}\text { lower Knosp grade; } \\
\text { lower Hardy-Wilson stage } \\
\text { smaller tumour diameter }\end{array}$ \\
\hline $\begin{array}{l}\text { Sarkar et al. [23] } \\
\text { (Vellore, India) }\end{array}$ & 2014 & 66 & $\begin{array}{l}\text { micro- and } \\
\text { macroadenomas }\end{array}$ & 28.8 & $\begin{array}{l}\mathrm{GH}<1 \mathrm{ng} / \mathrm{ml} \text { or } \\
\mathrm{GH} \text { after OGTT }<0.4 \mathrm{ng} / \mathrm{ml} \text {; } \\
\mathrm{IGF}-1 \text { normal }\end{array}$ & \\
\hline
\end{tabular}

OGTT = Oral glucose tolerance test; p.o. = postoperatively.

Initially, endoscopes were applied additionally during transsphenoidal microsurgery whenever it was deemed that their use might yield extra information [17]. More recently, they have become the more 'fashionable' visualisation tool for transsphenoidal surgery, and a current survey suggests that the majority of centres involved prefer endoscopy over microsurgery. However, the findings of such studies strictly depend on the centres selected, and a bias can easily result. The advantages of the use of an endoscope are the avoidance of a nasal speculum and of mucosal dissections as well as increased lateral, anterior and posterior visualisation even outside the straight line of sight. The need for postoperative nasal tamponades is generally avoided, and therefore a better subjective perception of surgery by patients because of free nasal ventilation is reported [18]. There are no more sublabial or nasal mucosal incisions. Instead, the instruments are advanced through one or both nasal cavities, and similar to a modified microsurgical approach [5], sphenoidotomy is performed. In many centres two surgeons cooperate. One of them traces the tumour by focusing the endoscope on the region of interest; the other manipulates the surgical instruments and aspirators.

It seems that everything that can be done under the visualisation of the operating microscope can also be achieved with the support of the microscope. The techniques used for tumour exposure, dissection, resection and skull base reconstruction are virtually identical to the microsurgical operative manipulations. To date, the results with pure endoscopic surgery in patients with acromegaly (table 1) in terms of normalisation of GH oversecretion $[19,20]$ have been excellent and absolutely com- 
parable to those achieved in series at centres where traditional microsurgery has been used $[10,15]$, but they have not been superior [21, 22]. Many tumours, particularly microadenomas, are localised close to the midline and can be visualised excellently and entirely with the operating microscope. Direct comparisons at individual centres also produced similar results $[20,23]$. It seems that the outcome of transsphenoidal surgery is dependent on the size and growth pattern of the tumour as well as on surgical experience rather than on the visualisation tool utilised for tumour extraction. At centres which switch from microsurgery to endoscopy, the learning curve that accompanies the collection of experience should not be neglected, but instead fully appreciated [24].

In an excellent attempt to validate the current place of endoscopic transsphenoidal surgery, Mortini [21] finds that in most series reported the operation times are longer, the manpower needed is greater, and the complication rates are higher, and there is more tissue destruction in endoscopic transsphenoidal surgery. One might be tempted to increase the risk of the operation occasionally, which could lead to avoidable morbidity. Biological factors determined by the tumour, such as encasement of the carotid artery, are definitely not resolved with endoscopic procedures; reports that might suggest this should be regarded as erroneous. Nevertheless, the endoscope is a valuable visualisation tool for transsphenoidal surgery that is absolutely comparable to the operating microscope. It offers advantages and disadvantages and could be a valuable asset in combination [17]. The wide angle of view allows an 'extended' transsphenoidal approach to parasellar lesions, which largely represent the classic contraindications to transsphenoidal surgery $[5,18]$. The results and complication rates assessed in expert centres and countrywide surveys show comparable figures.

\section{Intraoperative Magnetic Resonance Imaging}

An intraoperative estimation of the extent of tumour resection is generally made by the surgeons and depends on their ability to differentiate tissues and the complexity of the individual anatomy. Since, due to its superior soft tissue contrast, magnetic resonance imaging (MRI) most favourably depicts intracranial lesions, already in 1994 the first intraoperative system was introduced into clinical practice to determine the amount of brain tumour resection [25]. Since then many different intraoperative MRI systems have been installed throughout the world. Their main differences lie in the strength of the magnet,

Novel Techniques in Surgery of Acromegaly which directly determines the scanning time and image quality, as well as in the constructional setup that is needed. Due to the high cost of an MR scanner, the required shielding of the imaging room and restricted space, some neurosurgical centres prefer a 'twin room concept', where the MR scanner used for routine diagnostic imaging is shifted for intraoperative use into an operating theatre which is placed next door. In 'one-room' concepts, a dedicated MR scanner is located in the operating theatre. The patient is placed on a rotating or shifting operating table to be taken into the scanner [26].

Early intraoperative MR scanners did not exceed a magnetic field strength of $0.5 \mathrm{~T}$. By now some centres have already installed a 3-tesla scanner in their operating theatre. An intraoperative MR scanner up to $0.5 \mathrm{~T}$ is called a 'low-field' system, whereas scanners using $1.5 \mathrm{~T}$ and more are categorised into the group of 'high-field' systems. Their main advantage is comparability with standard pre- and postoperative imaging with a high image quality (fig. 2). In general, low-field MR scanners are able to detect suprasellar tumour remnants of 3-4 mm that are hidden from the surgeon's eye in folds of the descending sellar diaphragm [27] (table 2). Unfortunately, low-field MR scanners have a poor resolution in the region of the cavernous sinus [28]. High-field MR systems are clearly superior in the depiction of the parasellar space [29].

In general, a minimum of two imaging procedures are applied during an operation: imaging prior to resection and at the end of resection, when the surgeon feels that he has achieved the best possible tumour excision. If a residual tumour is depicted and resected, a further MR scan may demonstrate the improved radicalness of the resection [30]. Thus, intraoperative MRI increases the duration of general anaesthesia depending on the amount of images taken and the cost of the surgical procedure.

The authors currently use a data set of coronal and sagittal T2-weighted turbo spin-echo (TSE) images before and after resection for transsphenoidal surgery. They are accurate and rapidly acquired images which identify crucial anatomical landmarks and critical structures, and they excellently depict cystic components and allow differentiating residual tumours from haematomas within the resection cavity. Their acquisition takes approximately $15 \mathrm{~min}$. If one includes sterile draping of the head coil and moving the patient, the additional time of general anaesthesia is approximately $40 \mathrm{~min}$ per surgery. The visualisation of residual tumours unfortunately cannot be equated with the possibility of resecting them, and this is 
Fig. 2. Pre-, intra- and postoperative MRI studies in a 28-year-old patient with acromegaly who was re-operated for persistent disease on a combination therapy with octreotide and pegvisomant. For tumour progression on medical treatment, debulking surgery was advised. a Standard preoperative MRI (1.5 T; T1 with contrast). b Intraoperative MRI (1.5 T; T2 TSE) before tumour resection. c Intraoperative MRI (1.5 T; T2 TSE) after tumour resection. d Standard postoperative MRI (1.5 T; T1 with contrast) 3 months postoperatively.

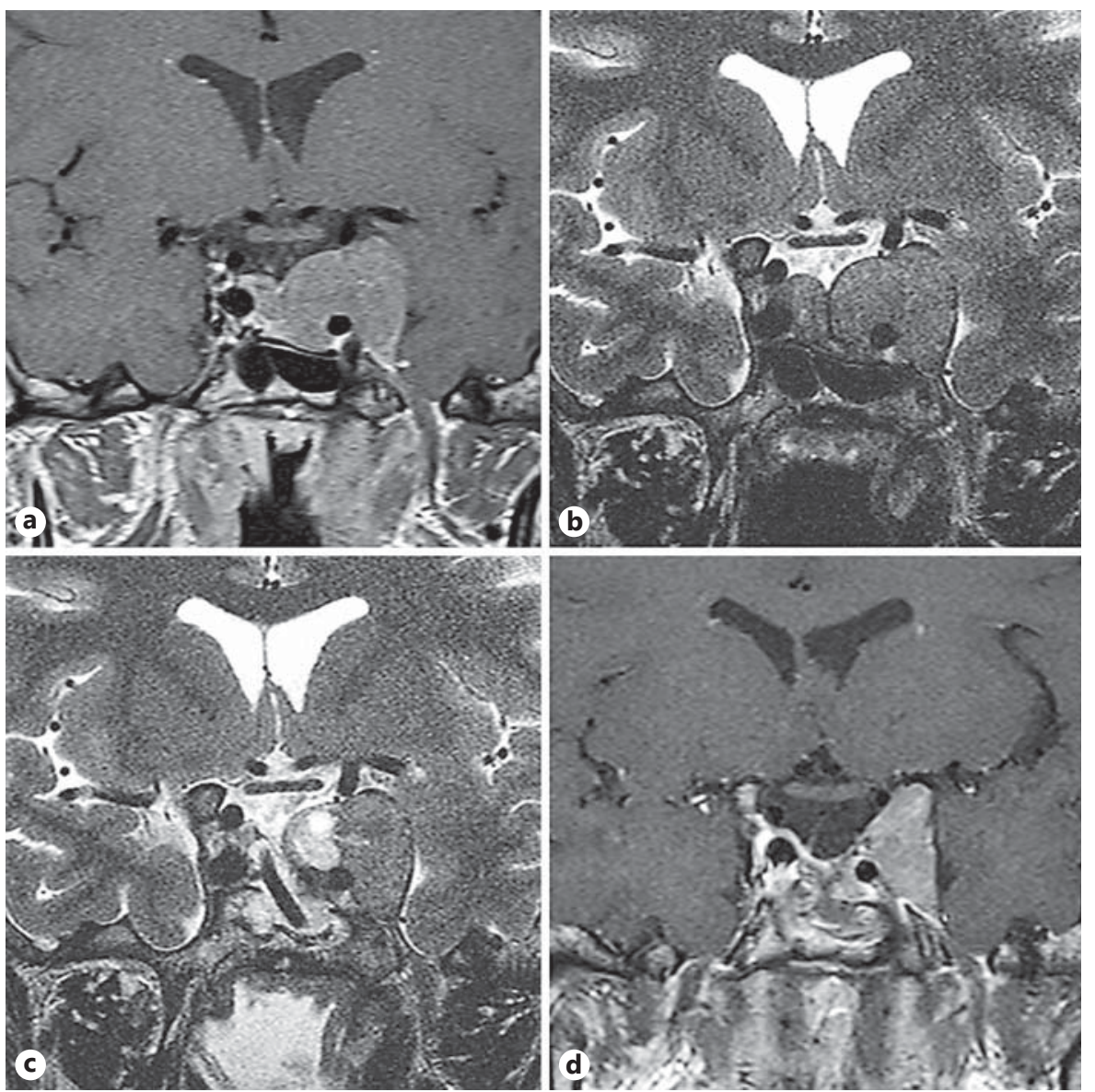

the major limitation of the system. However, when a residual tumour is suspected, the area can be checked again during the same operative procedure.

Several studies of low- and high-field intraoperative systems and their use in pituitary surgery have been published, and they show considerable advantages in terms of completed total resections and the amount of adenomatous tissue removed. Unfortunately, up to now only two series of acromegalic patients have been reported $[27,31]$.

In the series of Bellut et al. [31], by using a low-field system, complete resection was achieved in 38 out of 39 patients, based on intraoperative imaging. The limitations of the low-field scanners were obvious when the intraoperative images were compared to standard postoperative images 3 months after the surgery [26]: the rate of complete resection dropped from 38 to 31 patients when the standard MR images were critically analysed. Despite complete morphological tumour resection in 31 patients, overall endocrinological remission was only achieved in
Table 2. Indications for intraoperative MRI

- Pituitary tumours of considerable size

- Mainly supra-(retro-)sellar or subfrontal extension

- Redo procedures with insufficient resection at the primary attempt

- Complex tumour configuration, which suggests that the arachnoid does not descend in one fold

26 patients $(66.7 \%)$ when the most current criteria were applied [3]. Of those patients with intraoperatively detected residual tumour, which could be completely resected as well $(n=7)$, only 2 achieved biochemical remission.

Fahlbusch et al. [27] published a series of 23 selected patients with acromegaly in whom complete resection of the adenoma was assessed by intraoperative high-field MRI. They were able to increase the complete morphological adenoma resection rate from 56 to $77 \%$. However, 
Fig. 3. Macroadenoma in a 40-year-old male acromegalic patient with broad invasion into the right cavernous sinus. The $3 \mathrm{D}$ data set of the intraoperative MRI provides information such as the tumour volume (yellow) and the course of the carotid arteries (blue). Coronal (a) and sagittal (b) T2weighted and axial (c) T1-weighted images provide an excellent overview. The crucial structures can be superimposed onto the microsurgical operative field through the microscope (d).
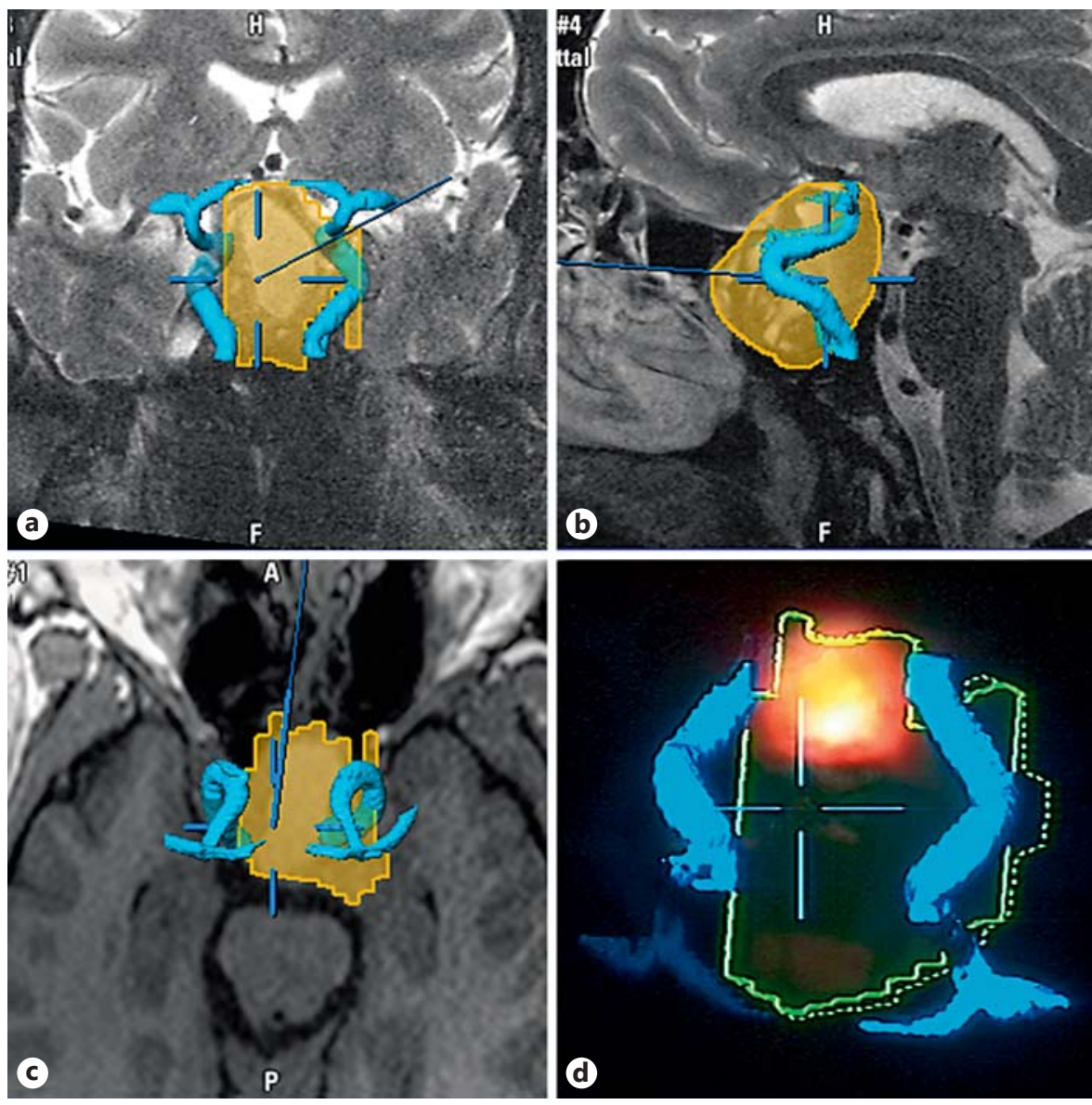

remission of GH and IGF-1 secretion was only achieved in $44 \%$ of those 18 patients in whom the tumour was completely resected.

Intraoperative MRI offers immediate feedback to the surgeon and is a perfect quality control for pituitary surgery. High-field systems provide a higher resolution of images within a shorter data acquisition time, but they require enormous investments. Experience in acromegalic patients is limited. Despite the most sophisticated intraoperative MRI visualisation, there are limits of resectability set by a tumour's quality, localisation and extension [26].

\section{Neuronavigation}

During a transsphenoidal operation, the surgeon obtains orientation by observing anatomical landmarks. However, the more minimally invasive the procedure becomes, the more reduced the overview provided. Thus, neuronavigation is increasingly used intraoperatively for the localisation of anatomical structures throughout cranial and spinal neurosurgery $[32,33]$. When he popularised transsphenoidal surgery, Hardy [34] introduced an image intensifier together with the operating microscope. Radiofluoroscopic control allowed for an increased confidence of the operator, since he could visualise radiopaque metal instruments projected against the skull base, which definitely made transsphenoidal surgery safer. Use of the image intensifier is still popular as a navigational aid worldwide [9].

However, there is no direct depiction of the tumour. Moreover, protective measures have to be taken, since the patient and all staff working in the operating theatre are exposed to the radiation. The information contained in the data sets provided by computerised tomography (CT) and particularly MRI can be used to enhance the surgeon's information with regard to the tumour's extent and anatomical neighbourhood, provided that they can be referenced to the operative field. Fiducials are markers 
Table 3. Indications for neuronavigation in transsphenoidal operations for acromegaly

\author{
Redo procedures \\ - Lack of anatomical landmarks \\ - Tissue defects \\ - Scarring \\ - Cisternal herniation \\ Incomplete pneumatisation of the sphenoid sinus \\ - Young children \\ - Thick clivus \\ Vascular anomalies \\ - Kinks and coils of the carotid artery \\ - 'Kissing carotids' \\ - Perisellar aneurysms \\ Concomitant pathology \\ - Congenital malformations \\ - Dual tumours \\ - McCune-Albright syndrome
}

that are fixed to the surface of the patient's head and recognised by either CT or MRI or by both methods. The strength of CT lies in the proper depiction of bony structures such as the clivus, the septations of the paranasal sinus and the cranial vault [35]. It thus allows distinguishing perfectly between skull base structures and air in the paranasal cavities. The strength of MRI lies in its high soft tissue contrast which delineates a pituitary adenoma from the cavernous sinus and intracranial nervous structures such as the optic chiasm.

Neuronavigation systems transfer information from the virtual reality of imaging data to the real world of the operative field and allow the surgeon to expect 'invisible' structures, since he can use the special anatomical location of their real position in the $3 \mathrm{D}$ world of an image (fig. 3). General use of navigation systems in operations of pituitary adenomas has been proposed by some authors, but this might actually not be necessary in centres with a high patient load [9]; it is certainly appreciated and undisputedly useful in every situation in which the anatomical relationships are more complex than normal (table 3) $[36,37]$. There are pointer-based systems which show the location of the pointer tip in a 3D CT or MRI model of the patient's head. The most sophisticated neuronavigation technology allows for a superposition of structures considered crucial for the performance of the operative procedure onto the operative field. The segmented course of the carotid artery and confines of a tumour are mostly used in this context. The contours can be switched on and off as needed. At all times, users of navigation systems have to be aware that what they see is the preoperative situation, i.e. when the data were generated. However, since in strict contrast to the ventricular system there is little brain shift to be expected at the level of the skull base, the assumed distances and locations can generally be trusted.

The respective studies describe the usefulness of navigation systems for all types of pituitary adenomas, but they do not focus on acromegaly $[36,38]$. We did not find any data in the medical literature that could be used to determine whether the efficacy of navigation-guided procedures is increased in acromegaly; currently, not even the assumption that complications can be avoided is based on evidence. This might be due to the small patient series, the lack of long-term outcome data and the fact that in experienced hands complication rates are low anyway $[9,10]$. The technology is equally useful for transsphenoidal microsurgery and endoscopic pituitary surgery $[36,37]$. With the advantages of neuronavigation, the spectrum of operable lesions has been widened. Neurosurgeons dare to approach lesions which they did not dare to touch in the past via the transsphenoidal route. For instance, it was simply unthinkable to operate upon such complex lesions as was done on a GH-secreting pituitary adenoma in a patient suffering from McCune-Albright syndrome and a huge concomitant fibroblastic skull base lesion into which the tumour was embedded [39]. With the advent of neuronavigation, however, the possibility of a surgical approach has been documented for several patients to date, with minimal morbidity.

\section{Ultrasound and Doppler Systems}

Since the equipment is relatively cheap, for a considerable time intraoperative ultrasound has been assessed for the intraoperative imaging of tumour extent and configuration. Ram et al. [40] mainly tried to localise intrasellar microadenomas in Cushing's disease, but they also assessed the size and extension of $3 \mathrm{GH}$-secreting pituitary macroadenomas. They could see the tumours mostly as hyperechoic masses and described that in macroadenomas the application of ultrasound unrestrictedly allowed visualising the interface between the tumour and the normal pituitary gland. The major disadvantage is that the results are highly dependent on the skills of the investigator. The inconsistency of depiction and the relatively low resolution prevented more widespread use.

In contrast, what is certainly very helpful is the application of the Doppler probe to localise the carotid artery,
Buchfelder/Schlaffer 

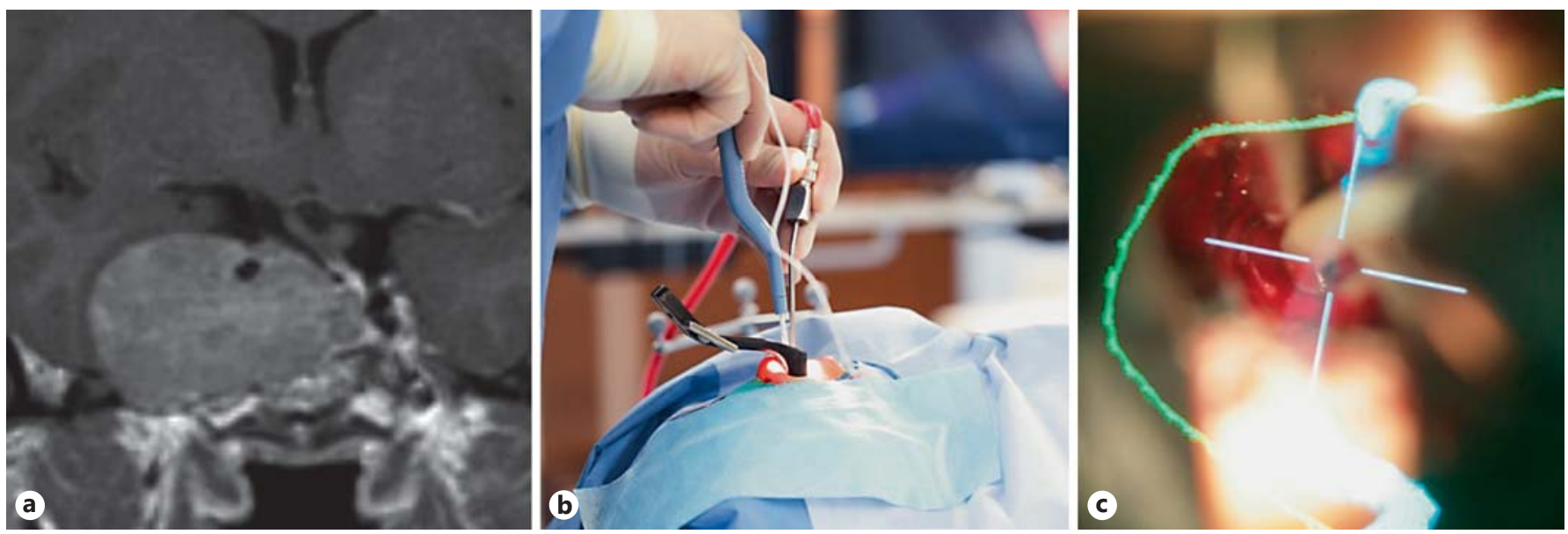

Fig. 4. Invasive, progressive macroadenoma after 2 transsphenoidal operations in a 44-year-old female with total encasement of the right internal carotid artery (a). Intraoperative microvascular Doppler (b) and neuronavigation (c) were helpful in localising the internal carotid artery.

which frequently is very close to the lateral tumour margins and sometimes even kinks into the sellar space. Lesions of the carotid artery with brisk arterial bleeding which is extremely difficult to control and presents a possibly life-threatening situation - are one of the nightmares of the transsphenoidal surgeon. Dusick et al. [41] describe the use of a Doppler probe to locate the carotid artery through the dura and prevent a lesion of the carotid artery by detaching the structures with a blade hook. The Doppler probe is used ubiquitously in aneurysm surgery to ascertain the patency of parent vessels and to document the complete occlusion of a vascular malformation. There are no specific reports on the usefulness of this technique in acromegalic patients, but it is certainly to be generally recommended, since it is not associated with major costs, is readily available and increases the safety of the procedure. Although there is a lack of objective outcome literature demonstrating its distinct benefits, there is no doubt that the microvascular Doppler system has clearly helped to lower the incidence of carotid artery injuries. Figure 4 shows the application of the system in a tumour with total arterial encasement.

\section{Intraoperative GH Measurements}

Various groups have assessed the value of intraoperative $\mathrm{GH}$ measurements in improving the outcome of surgery for acromegaly. The underlying pathophysiological concept is easy to understand with a complete tumour excision: with resection of all secreting tissue, the source of the GH secretion is completely eliminated. Thus, GH should be eliminated from the circulation according to its half-life - which, roughly estimated, lies between 20 and $30 \mathrm{~min}$. In a successful operation in which GH is determined intra- and perioperatively, it drops to subnormal levels within 10 half-life periods. Theoretically, the lack of an adequate decrease in GH could be used to identify residual tumour. However, only Abe and Lüdecke [42] reported on a dramatic improvement of their results from intraoperative measurements in patients with acromegaly treated by transsphenoidal surgery. Other authors are more critical in respect to this technique. Valdemarsson et al. [43] compared the $\mathrm{GH}$ half-life data to corresponding results obtained from GH measurements between 60 and 100 min after adenomectomy and commented that intraoperative GH half-life measurements should be interpreted with caution. Valdemarsson et al. [44] found differing half-lives between those patients who went into remission after surgery and those who did not remit. Moreover, in several of their patients, they could not calculate half-lives at all. They measured GH with a sensitive and rapid assay by which the results could be reported within $40 \mathrm{~min}$. However, they commented that the results obtained were not used in their study for perioperative decisions. Otani et al. [45] measured GH in blood samples obtained before surgery, at the start of tumour removal and every 20 min thereafter until 20 min after tumour resection. Among several criteria in- 
dicating total tumour removal, only the level of serum GH 20 min after the end of tumour excision was significantly different between those patients who remitted according to the Cortina Consensus Criteria [8] and those in which the disease persisted after surgery.

There are some technical and organisational problems with intraoperative $\mathrm{GH}$ measurements. Intraoperative blood sampling and determination of $\mathrm{GH}$ levels requires mathematical models in which the intraoperative decrease can be used to predict the extent of resection. In summary, the technique is time-consuming and requires laboratory facilities for rapid intraoperative GH assessments, which is why it has failed to find its way into routine practice and surgery [46].

\section{Conclusions}

A few novel technologies and procedures have been introduced for the surgical treatment of acromegaly. To date, the most important ones have been the use of endoscopy and intraoperative MRI in transsphenoidal surgery. With both of these methods residual tumours can be visualised and the rate of gross total resections increased. By neuronavigation and the use of the Doppler probe to localise the carotid artery, severe complications can be avoided. The value of intraoperative $\mathrm{GH}$ measurements in acromegaly has until now not been convincingly shown.

For further reading on acromegaly in this issue, see [51-60].

\section{References}

1 Katznelson L: Pituitary function: acromegaly: where are we now? Nat Rev Endocrinol 2009; 5:420-422.

2 Katznelson L, Laws ER Jr, Melmed S, Molitch ME, Murad MH, Utz A, Wass JA: Acromegaly: an Endocrine Society clinical practice guideline. J Clin Endocrinol Metab 2014;99: 3933-3951.

-3 Giustina A, Chanson P, Bronstein MD, Klibanski A, Lamberts S, Casanueva FF, Trainer P, Ghigo E, Ho K, Melmed S: A consensus on criteria for cure of acromegaly. J Clin Endocrinol Metab 2010;95:3141-3148.

-4 Campbell PG, Kenning E, Andrews DW, Yadla S, Rosen M, Evans JJ: Outcomes after a purely endoscopic transsphenoidal resection of growth hormone-secreting pituitary adenomas. Neurosurg Focus 2010;29:E5.

5 Cappabianca P, Cavallo LM, de Divitiis E: Endoscopic endonasal transsphenoidal surgery. Neurosurgery 2004;55:933-940.

-6 Swearingen B, Barker FG 2nd, Katznelson L, Biller BM, Grinspoon S, Klibanski A, Moayeri N, Black PM, Zervas NT: Long-term mortality after transsphenoidal surgery and adjunctive therapy for acromegaly. J Clin Endocrinol Metab 1998;83:3419-3426.

7 Ronchi CL, Varca V, Giavoli C, Epaminonda P, Beck-Peccoz P, Spada A, Arosio M: Longterm evaluation of postoperative acromegalic patients in remission with previous and newly proposed criteria. J Clin Endocrinol Metab 2005;90:1377-1382.

-8 Giustina A, Barkan A, Casanueva FF, Cavagnini F, Frohman L, Ho K, Veldhuis J, Wass J, Von Werder K, Melmed S: Criteria for cure of acromegaly: a consensus statement. J Clin Endocrinol Metab 2000;85:526-529.

9 Buchfelder M: Treatment of pituitary tumors: surgery. Endocrine 2005;28:67-75.
10 Mortini P, Losa M, Barzaghi R, Boari N, Giovanelli M: Results of transsphenoidal surgery in a large series of patients with pituitary adenoma. Neurosurgery 2005;56:1222-1233.

11 Buchfelder M, Fahlbusch R: The 'classic' transsphenoidal approach for resection of pituitary tumors. Oper Tech Neurosurg 2002; 5:210-217.

$\$ 12$ Couldwell WT: Transsphenoidal and transcranial surgery for pituitary adenomas. J Neurooncol 2004;69:237-256.

$\checkmark 13$ Colao A, Attanasio R, Pivonello R, Cappabianca P, Cavallo LM, Lasio G, Lodrini A, Lombardi G, Cozzi R: Partial surgical removal of growth hormone-secreting pituitary tumors enhances the response to somatostatin analogs in acromegaly. J Clin Endocrinol Metab 2006;91:85-92.

14 Melmed S, Casanueva FF, Cavagnini F, Chanson P, Frohman L, Grossman A, Ho K, Kleinberg D, Lamberts S, Laws E, Lombardi G, Vance ML, Werder KV, Wass J, Giustina A: Guidelines for acromegaly management. J Clin Endocrinol Metab 2002;87:4054-4058.

15 Kreutzer J, Vance ML, Lopes MB, Laws ER Jr: Surgical management of GH-secreting pituitary adenomas: an outcome study using modern remission criteria. J Clin Endocrinol Metab 2001;86:4072-4077.

16 Jho HD, Carrau RL: Endoscopy assisted transsphenoidal surgery for pituitary adenoma. Technical note. Acta Neurochir (Wien) 1996;138:1416-1425.

17 McLaughlin N, Eisenberg AA, Cohan P, Chaloner CB, Kelly DF: Value of endoscopy for maximizing tumor removal in endonasal transsphenoidal pituitary adenoma surgery. J Neurosurg 2013;118:613-620.

18 Solari D, Cavallo LM, Cappabianca P: Surgical approach to pituitary tumors. Handb Clin Neurol 2014;124:291-301.
19 Jane JA Jr, Starke RM, Elzoghby MA, Reames DL, Payne SC, Thorner MO, Marshall JC, Laws ER Jr, Vance ML: Endoscopic transsphenoidal surgery for acromegaly: remission using modern criteria, complications, and predictors of outcome. J Clin Endocrinol Metab 2011;96:2732-2740.

20 Starke RM, Raper DM, Payne SC, Vance ML, Oldfield EH, Jane JA Jr: Endoscopic vs microsurgical transsphenoidal surgery for acromegaly: outcomes in a concurrent series of patients using modern criteria for remission. J Clin Endocrinol Metab 2013;98:3190-3198.

21 Mortini P: Cons: endoscopic endonasal transsphenoidal pituitary surgery is not superior to microscopic transsphenoidal surgery for pituitary adenomas. Endocrine 2014;47:415420.

22 Ammirati M, Wei L, Ciric I: Short-term outcome of endoscopic versus microscopic pituitary adenoma surgery: a systematic review and meta-analysis. J Neurol Neurosurg Psychiatry 2013;84:843-849.

-23 Sarkar S, Rajaratnam S, Chacko G, Chacko AG: Endocrinological outcomes following endoscopic and microscopic transsphenoidal surgery in 113 patients with acromegaly. Clin Neurol Neurosurg 2014;126:190-195.

24 Laws ER Jr, Barkhoudarian G: The transition from microscopic to endoscopic transsphenoidal surgery: the experience at Brigham and Women's Hospital. World Neurosurg 2014; 82:S152-S154.

25 Black PM, Moriarty T, Alexander E 3rd, Stieg P, Woodard EJ, Gleason PL, Martin CH, Kikinis R, Schwartz RB, Jolesz FA: Development and implementation of intraoperative magnetic resonance imaging and its neurosurgical applications. Neurosurgery 1997;41:831-842. 
26 Buchfelder M, Schlaffer SM: Intraoperative magnetic resonance imaging during surgery for pituitary adenomas: pros and cons. Endocrine 2012;42:483-495.

-27 Fahlbusch R, Keller B, Ganslandt O, Kreutzer J, Nimsky C: Transsphenoidal surgery in acromegaly investigated by intraoperative highfield magnetic resonance imaging. Eur J Endocrinol 2005;153:239-248.

28 Gerlach R, du Mesnil de Rochemont R, Gasser T, Marquardt G, Reusch J, Imoehl L, Seifert V: Feasibility of Polestar N20, an ultra-low-field intraoperative magnetic resonance imaging system in resection control of pituitary macroadenomas: lessons learned from the first 40 cases. Neurosurgery 2008;63:272-284.

29 Nimsky C, Ganslandt O, Fahlbusch R: Comparing 0.2 tesla with 1.5 tesla intraoperative magnetic resonance imaging: analysis of setup, workflow, and efficiency. Acad Radiol 2005;12:1065-1079.

30 Nimsky C, von Keller B, Ganslandt O, Fahlbusch R: Intraoperative high-field magnetic resonance imaging in transsphenoidal surgery of hormonally inactive pituitary macroadenomas. Neurosurgery 2006;59:105-114.

- 31 Bellut D, Hlavica M, Schmid C, Bernays RL Intraoperative magnetic resonance imagingassisted transsphenoidal pituitary surgery in patients with acromegaly. Neurosurg Focus 2010;29:E9.

- 32 Barone DG, Lawrie TA, Hart MG: Image guided surgery for the resection of brain tumours. Cochrane Database Syst Rev 2014;1: CD009685.

-33 Moses ZB, Mayer RR, Strickland BA, Kretzer RM, Wolinsky JP, Gokaslan ZL, Baaj AA: Neuronavigation in minimally invasive spine surgery. Neurosurg Focus 2013;35:E12.

34 Hardy J: Transphenoidal microsurgery of the normal and pathological pituitary. Clin Neurosurg 1969;16:185-217.

35 Lucas JW, Zada G: Imaging of the pituitary and parasellar region. Semin Neurol 2012;32: 320-331.

- 36 Thomale UW, Stover JF, Unterberg AW: The use of neuronavigation in transnasal transsphenoidal pituitary surgery. Zentralbl Neurochir 2005;66:126-132.

- 37 Lasio G, Ferroli P, Felisati G, Broggi G: Imageguided endoscopic transnasal removal of recurrent pituitary adenomas. Neurosurgery 2002;51:132-136
38 Duque SG, Gorrepati R, Kesavabhotla K, Huang C, Boockvar JA: Endoscopic endonasal transphenoidal surgery using the Brain$\mathrm{LAB}^{\circledR}$ Headband for navigation without rigid fixation. J Neurol Surg A Cent Eur Neurosurg 2014;75:267-269.

39 Dou W, Lin N, Ma W, Yang Y, Zhu H, Sun J, Lian W, Yang Z, Li W, Wang R: Transsphenoidal surgery in a patient with acromegaly and McCune-Albright syndrome: application of neuronavigation. J Neurosurg 2008; 108 : 164-169.

40 Ram Z, Shawker TH, Bradford MH, Doppman JL, Oldfield EH: Intraoperative ultrasounddirected resection of pituitary tumors. J Neurosurg 1995;83:225-230.

41 Dusick JR, Esposito F, Malkasian D, Kelly DF: Avoidance of carotid artery injuries in transsphenoidal surgery with the Doppler probe and micro-hook blades. Neurosurgery 2007; 60:322-328.

42 Abe T, Lüdecke DK: Recent primary transnasal surgical outcomes associated with intraoperative growth hormone measurement in acromegaly. Clin Endocrinol (Oxf) 1999;50: 27-35.

43 Valdemarsson S, Bramnert M, Cronquist S, Elner A, Eneroth CM, Hedner P, LindvallAxelsson M, Nordström CH, Strömblad LG: Early postoperative basal serum GH level and the GH response to TRH in relation to the long-term outcome of surgical treatment for acromegaly: a report on 39 patients. J Intern Med 1991;230:49-54.

44 Valdemarsson S, Ljunggren S, Cervin A, Svensson C, Isaksson A, Nordström CH, Siesjö P: Evaluation of surgery for acromegaly: role of intraoperative growth hormone measurement? Scand J Clin Lab Invest 2001;61 459-470.

45 Otani R, Fukuhara N, Ochi T, Oyama K, Yamada S: Rapid growth hormone measurement during transsphenoidal surgery: analysis of 252 acromegalic patients. Neurol Med Chir (Tokyo) 2012;52:558-562.

46 Katznelson L, Atkinson JL, Cook DM, Ezzat SZ, Hamrahian AH, Miller KK: American Association of Clinical Endocrinologists Medical Guidelines for Clinical Practice for the Diagnosis and Treatment of Acromegaly - 2011 update: executive summary. Endocr Pract 2011;17:636-646.

47 Hofstetter CP, Mannaa RH, Mubita L, Anand VK, Kennedy JW, Dehdashti AR, Schwartz TH: Endoscopic endonasal transsphenoidal surgery for growth hormone-secreting pituitary adenomas. Neurosurg Focus 2010;29:E6.
8 Yildirim AE, Sahinoglu M, Divanlioglu D, Alagoz F, Gurcay AG, Daglioglu E, Okay HO, Belen AD: Endoscopic endonasal transsphenoidal treatment for acromegaly: 2010 consensus criteria for remission and predictors of outcomes. Turk Neurosurg 2014;24:906-912.

49 Gondim JA, Almeida JP, de Albuquerque LA Gomes E, Schops M, Ferraz T: Pure endoscopic transsphenoidal surgery for treatment of acromegaly: results of 67 cases treated in a pituitary center. Neurosurg Focus 2010; 29:E7.

50 Shin SS, Tormenti MJ, Paluzzi A, Rothfus WE, Chang YF, Zainah H, Fernandez-Miranda JC, Snyderman CH, Challinor SM, Gardner PA: Endoscopic endonasal approach for growth hormone secreting pituitary adenomas: outcomes in 53 patients using 2010 consensus criteria for remission. Pituitary 2013. 16:435-444.

51 de Herder WW: The history of acromegaly. Neuroendocrinology 2016;103:7-17.

52 Schernthaner-Reiter MH, Trivellin G, Stratakis CA: MEN1, MEN4, and carney complex: pathology and molecular genetics. Neuroendocrinology 2016;103:18-31.

53 Hannon MJ, Barkan AL, Drake WM: The role of radiotherapy in acromegaly. Neuroendocrinology 2016;103:42-49.

54 Chanson P: Medical treatment of acromegaly with dopamine agonists or somatostatin analogs. Neuroendocrinology 2016;103:50-58

55 Neggers SJCMM, Muhammad A, van der Lely AJ: Pegvisomant treatment in acromegaly. Neuroendocrinology 2016;103:59-65.

56 McCabe J, Ayuk J, Sherlock M: Treatment factors that influence mortality in acromegaly. Neuroendocrinology 2016;103:66-74.

57 Powlson AS, Gurnell M: Cardiovascular disease and sleep-disordered breathing in acromegaly. Neuroendocrinology 2016;103:75-85.

58 Claessen KMJA, Mazziotti G, Biermasz NR, Giustina A: Bone and joint disorders in acromegaly. Neuroendocrinology 2016;103:86-95.

59 Dal J, List EO, Jørgensen JOL, Berryman DE: Glucose and fat metabolism in acromegaly: from mice models to patient care. Neuroendocrinology 2016;103:96-105.

60 Webb SM, Badia X: Quality of life in acromegaly. Neuroendocrinology 2016;103:106-111.
Novel Techniques in Surgery of Acromegaly
Neuroendocrinology 2016;103:32-41 DOI: $10.1159 / 000441980$ 